\begin{tabular}{l|l|l} 
Jurnal Eksplorasi Akuntansi & $\begin{array}{l}\text { Vol. 2, No 1, Seri B, Februari 2020, Hal 2214-2233 } \\
\text { ISSN : 2656-3649 (Online) } \\
\text { http://jea.ppj.unp.ac.id/index.php/jea/issue/view/18 }\end{array}$
\end{tabular}

\title{
ANALISIS GAMBAR "KESETARAAN GENDER" DALAM DUNIA DIGITAL: SEBUAH EKSPLORASI PADA IKATAN AKUNTAN INDONESIA
}

\author{
M. Ridho Hidayat ${ }^{1}$, Sany Dwita ${ }^{2}$ \\ ${ }^{1}$ Alumni Jurusan Akuntansi Fakultas Ekonomi Universitas Negeri Padang \\ ${ }^{2}$ Jurusan Akuntansi Fakultas Ekonomi Universitas Negeri Padang \\ *Korespondensi: mridhohidayat17@gmail.com
}

\begin{abstract}
The purpose of this study is to analyse how website of Institute of Indonesia Chartered Accountants contribute in gender equality of accounting profession in Indonesia. The processes of constructing and redesigning website and the selection of the images that appearing on it are analysed as important mechanism which not only reflect 'realities', but also contribute to proliferation diachronically existed power relations, gender inequalities, and gendered hierarchies. This study finds a proliferation of images of (accounting) women on structure of the profession even if men are still dominant. The outcome of this to encourage women participation in accounting profession. The empirical proof presented in this study, points toward a lack of images representing professional accounting women. But when women are represented, they are depicted in similar roles as like men roles. These findings explain that Institute of Indonesia Chartered Accountants has become progressive and attempted to reduce the exercises of gender inequality in the accounting profession and contribute to empower gender equality. This study argues that a proliferation in the representation of (accounting) women in Indonesia digital space would flourish a positive step towards the inclusion of women in the Indonesia profession.
\end{abstract}

Keywords : Gender, Equality, Accounting Profession, Inclusion.

How to cite (APA $6^{\text {th }}$ style)

Hidayat, M. R \& Dwita, Sany. (2020). Analisis Gambar "Kesetaraan Gender" Dalam Dunia Digital: Sebuah Eksplorasi Pada Ikatan Akuntan Indonesia. Jurnal Eksplorasi Akuntansi. 2(1), Seri B, 2214-2233.

\section{PENDAHULUAN}

Dalam profesi akuntansi, ketidaksetaraan gender memicu munculnya glass ceiling yang menghambat atau mencegah pertumbuhan perempuan dalam menjadi akuntan profesional dan menciptakan ketidaksetaraan gaji pada laki-laki dan perempuan meskipun kinerja yang dihasilkan sama pada fungsi yang sama (Silva, Magro, \& Silva, 2016; Brighenti et al 2015). Glass Ceiling merupakan istilah yang menggambarkan bahwa adanya hambatan berupa bias persepsi terhadap perempuan dalam masyarakat sehingga adanya kesenjangan representasi dan gaji antara laki-laki dan perempuan dalam profesi, hal ini diakibatkan oleh munculnya paradigma 
pengecualian perempuan pada jabatan yang tinggi dalam hirarki bahkan pada posisi manajerial (Silva et al, 2016).

Studi profesi akuntansi pada dunia digital telah menyediakan ruang pengetahuan menarik yang bertujuan untuk meningkatkan efisiensi organisasi, pengembangan dunia bisnis, menarik perhatian calon pelanggan dan menyampaikan informasi (Borgia \& Shrager, 2000; Chen et al 2005; Chou \& Cheng, 2012; Luthy \& Carver, 2004; Roxas, Peek, \& Peek, 2000). Cabang dari literatur tersebut telah menarik perhatian para peneliti pada fitur teknis dan isi website, tanpa menguji hubungannya pada lingkup sosial yang lebih luas, politik dan konteks ekonomi (Kyriacou, 2016).

Penelitian yang menjadikan Institusi Profesional Akuntansi sebagai objek penelitian masih tergolong terbatas. Salah satu Penelitian ini dapat ditemukan di Yunani. Kyriacou (2016) melakukan penelitian pada Institusi Akuntansi Profesional di Yunani (SOEL) dan hasil penelitian tersebut menjelaskan bahwa masih minimnya gambar yang merepresentasikan akuntan profesional perempuan. Namun, penelitian tersebut setuju dengan adanya peningkatan representasi gambar akuntan profesional perempuan di dunia digital merupakan sinyal positif bagi perempuan dalam profesi akuntansi, karena dapat meredam stigma ketidaksetaraan gender dalam profesi (Kyriacou, 2016).

Ikatan Akuntan Indonesia (IAI) memiliki misi untuk berpartisipasi aktif di dalam mewujudkan good governance upaya yang sah dan dalam perspektif nasional dan internasional (IAI, 2019). Kemenpppa (2016) mengungkapkan pada masyarakat yang merupakan bagian dari good governance terus digiatkan dengan mendorong berbagai organisasi dalam urusan pokok pemberdayaan perempuan, kesetaraan gender dan pemberdayaan anak. Hal ini mengisyaratkan bahwa IAI memiliki tanggung jawab sosial dalam isu kesetaraan gender ini demi menciptakan perkembangan profesi yang lebih baik dan mencapai misi yang telah dicanangkan sebelumnya.

Penelitian ini bertujuan untuk melihat apakah IAI yang memiliki misi dan tanggung jawab sosial untuk meredam isu ketidaksetaraan gender dalam profesi akuntansi telah melakukan perannya dengan baik atau tidak melalui publikasi foto yang terdapat pada website resmi IAI. Peran tersebut terindikasi baik apabila adanya upaya IAI untuk mempublikasikan foto atau gambar laki-laki dan perempuan pada website secara seimbang baik dari segi komposisi maupun peran. Sebaliknya, jika IAI lebih cenderung mempublikasikan foto atau gambar yang lebih di dominasi oleh laki-laki, maka IAI terindikasi belum menjalankan perannya dengan baik (Kyriacou, 2016).

\section{REVIU LITERATUR}

\section{Teori Stratifikasi Gender (Gender Stratification Theory)}

Teori stratifikasi gender adalah teori yang menjelaskan bahwa perempuan tidak mendapatkan kesempatan yang sama seperti laki-laki, atas dasar gender yang dimilikinya. Teori stratifikasi gender dapat diterapkan pada ruang lingkup situasi yang lebih luas (Brinton, 1998; Dubose, 2017; Keister dan Southgate, 2012) dan termasuk kondisi perbandingan historis (Wermuth dan Monges, 2002; Scott, 1986). Stratifikasi gender ini membatasi akses perempuan dalam hal mencapai kekuasaan, prestise, dan kepemilikan berdasarkan gender (Treas dan Tai, 2016; Collins et al, 1993). Stratifikasi gender ini juga bisa disebut dengan ketidaksetaraan gender.

Terkait dengan teori stratifikasi gender, muncul beberapa konsep seperti akses differensial, distribusi pekerjaan, dan glass ceiling. Konsep glass ceiling menekankan pada ide bahwa perempuan mengalami kesulitan untuk mencapai level yang lebih tinggi dalam sebuah 
profesi atau pekerjaan karena adanya hambatan (ceiling). Hambatan-hambatan tersebut dapat berasal dari tradisi masyarakat, internal perusahaan/profesi dan lemahnya pengawasan dan aturan dari pemerintah (Treas dan Tai, 2016; Baxter dan Wright, 2000; Bell et al. 2002; Goodman, et al., 2003; Broadbent dan Kirkham, 2008; Bryant, 2010). Beberapa konsep inilah yang menyebabkan perempuan sulit mendapat promosi jabatan, ketidaksetaraan gaji dalam pekerjaan, serta akses terbatas dalam pekerjaan.

Dari sudut pandang sosiologi, teori stratifikasi gender menjelaskan ide kemunculan ketidaksetaraan gender bermaksud untuk menciptakan sebuah sistem, sosial, yang dimana salah satu bagian dari populasi akan memikul tanggung jawab atas bagian pekerjaan tertentu, sementara bagian lainnya bertanggung jawab atas bagian pekerjaan tertentu (Brinton, 1998; Dubose, 2017; Keister dan Southgate, 2012). Ketidaksetaraan yang bersumber dari gender, muncul untuk menciptakan perbedaan dalam tingkatan tanggung jawab. Isu utamanya adalah adanya kecenderungan satu grup dalam sebuah grup sosial menjadi dominan dan mungkin menekan grup lainnya (Treas dan Tai, 2016).

\section{Teori Komunikasi}

Dalam konteks Habermas, penelitian ini berpendapat bahwa gambar yang tersedia pada website resmi institusi memiliki nilai karena gambar tersebut merupakan klaim validitas perusahaan ketika perusahaan mencari pemahaman dan pengertian dengan anggota masyarakat. Dalam rangka untuk memenuhi syarat sebagai sarana komunikasi yang lebih efektif, akuntansi yang merupakan media komunikasi harus menyampaikan informasi tentang intersubjektif yang menguntungkan semua masyarakat untuk memastikan bahwa lifeworld dari masyarakat muncul dalam bentuk yang paling seimbang dan rasional (Habermas dalam Kuarisikun, 2011). Oleh sebab itu penelitian ini mencoba untuk menganalisis gambar dalam website resmi institusi dan memaknai gambar tersebut berkaitan dengan proses komunikasi dan rasionalisasi lifeworld dalam kehidupan akuntansi di Indonesia.

Sugiharti (2014:43-44), menyintesiskan teori komunikasi yang diutarakan Habermas, teori yang dikaji pada penelitian aksi komunikatif mewakili dasar kerangka teori sosial yang dibangun dalam tradisi Marxis, Weber, dan teori kritis klasik. Habermas memberikan pengertian yang berbeda antara kerja dan interaksi sosial. Dalam beberapa karyanya Habermas sering menggunakan istilah tindakan komunikatif untuk mendeskripsikan mengapa individu dapat melakukan interaksi sosial dan mencapai tujuannya dengan syarat mereka dapat mengharmonisasikan rencana bertindak mereka sesuai dengan definisi situasi bersama.

Website Resmi merupakan alat bagi organisasi profesi untuk menyampaikan informasi terkait organisasi profesi dan regulasi serta materi profesi kepada para anggota, profesi, maupun masyarakat umum. Melalui website, organisasi profesi berupaya untuk mengungkapkan realitas dan informasi yang telah dibentuk oleh organisasi profesi. Website tidak hanya menyediakan informasi mengenai regulasi dan materi terkait profesi yang bersifat eksplisit, tetapi juga menyediakan informasi yang bersifat implisit (Kyriacou, 2016). Akuntansi dapat disebut sebagai sebuah bahasa, karena akuntansi memiliki sifat leksikal maupun gramatikal (Belkaoui, 1980).

\section{Gender di Indonesia}

Pembahasan tentang gender akan sangat erat kaitannya dengan konsep ketidaksetaraan gender (Mansour, 2013). Bahkan perbedaan gender dianggap sebagai konsep yang melahirkan ketidaksetaraan gender. Konsep perbedaan gender membahas mengenai adanya perbedaan antara laki-laki dan perempuan. Sementara konsep ketidaksetaraan gender mengacu pada 
ketidakseimbangan/ diskriminasi posisi seorang perempuan terhadap posisi laki-laki dalam tatanan kehidupan masyarakat yang sedang berjalan. Ketidaksetaraan gender adalah sebuah sistem dan struktur dimana baik kaum laki-laki dan perempuan menjadi korban dari sistem tersebut. Terdapat berbagai manifestasi ketidaksetaraan gender menurut Mansour (2013), yaitu :

1. Marginalisasi Perempuan

Proses marginalisasi terhadap perempuan melahirkan pemiskinan terhadap perempuan. Marginalisasi terhadap perempuan sudah terjadi sejak di rumah tangga dalam bentuk diskriminasi atas anggota keluarga yang laki-laki dan perempuan. Marginalisasi tersebut juga diperkuat oleh adat istiadat maupun tafsir agama tertentu.

2. Subordinasi Perempuan

Subordinasi perempuan terjadi karena munculnya anggapan bahwa perempuan memiliki sifat irrasional dan emosional sehingga perempuan tidak mampu menjadi pemimpin sehingga memunculkan sikap yang menempatkan perempuan pada posisi yang tidak lebih penting dibandingkan laki-laki. Sebagai contoj dalam proses pengambilan keputusan dalam keluarga harus berdasarkan persetujuan laki-laki.

3. Stereotip terhadap Perempuan

Stereotip adalah sebuah label yang disematkan pada suatu kelompok tertentu. Terdapat banyak ketidakadilan terhadap jenis kelamin tertentu, umumnya perempuan yang bersumber dari pelabelan (stereotip) yang dilekatkan pada perempuan. Misalnya adalah adanya asumsi bahwa tugas utama perempuan adalah melayani suami.

4. Beban Kerja

Terdapat banyak perempuan yang melakukan pekerjaan domestik dan dianggap sebagai pekerjaan yang lebih rendah daripada pekerjaan yang dilakukan laki-laki. Terlebih jika perempuan tersebut bekerja dalam wilayah publik maka beban kerja perempuan akan menjadi ganda (double burden). Pembagian dan perbedaan gender juga menyebabkan perempuan bekerja lebih keras dengan memeras keringat jauh lebih berat (double burden). Ada beberapa pekerjaan yang dilakukan laki-laki, dilakukan juga oleh perempuan. Untuk perempuan yang bekerja, artinya mereka memiliki peran ganda, yaitu bekerja di rumah dan di luar rumah.

\section{Gender Dalam Profesi Akuntansi Indonesia}

Dalam Profesi Akuntansi, ketidaksetaraan gender menghambat atau mencegah pertumbuhan perempuan dalam menjadi akuntan profesional dan menciptakan ketidaksetaraan gaji pada laki-laki dan perempuan meskipun kinerja yang dihasilkan sama pada fungsi yang sama (Silva et al, 2016; Brighenti et al, 2015). Glass Ceiling merupakan istilah yang menggambarkan bahwa adanya hambatan berupa bias persepsi terhadap perempuan dalam masyarakat sehingga adanya kesenjangan representasi dan gaji antara laki-laki dan perempuan dalam profesi, hal ini diakibatkan oleh munculnya paradigma pengecualian perempuan pada jabatan yang tinggi dalam hirarki bahkan pada posisi manajerial (Silva et al, 2016).

Indonesia yang memiliki paham patriarki menciptakan adanya istilah maskulinitas dalam akuntansi. Maskulinitas akuntansi ini mendorong kurang dapat diterimanya perempuan dalam profesi ini dan menganggap laki-laki yang lebih pantas pada profesi ini dan pada akhirnya menyebabkan adanya ketimpangan gender dalam profesi akuntan (Kirkham dan Loft, 1993). Ketimpangan berbias gender ini tidak hanya direfleksikan dengan adanya pandangan bahwa perempuan tidak cocok menangani pekerjaan akuntansi, akan tetapi juga tercermin dari rasio gaji yang diperoleh pekerja laki-laki dan perempuan dalam bidang akuntansi. Selain itu terdapat juga 
hambatan atau halangan yang terselubung bagi perempuan untuk melanjutkan jenjang karir yang lebih tinggi (Kim, 2001; Stedham et al., 2003).

Dalam profesi sebagai akuntan publik jumlah perempuan telah meningkat secara drastis (Murtanto, 2003). Perkembangan perempuan di bidang akuntansi telah mencerminkan suatu perjuangan yang sangat panjang untuk mengatasi penghalang dan batasan yang diciptakan oleh sistem struktur sosial yang kaku, diskriminatif, konsep ketidakadilan dan konflik antar rumah tangga serta karir (Ried , 1987). Namun secara perlahan, struktur sosial yang kaku tersebut telah mulai lenyap seiring perkembangan zaman. Dengan diangkatnya isu kesetaraan gender dalam ranah nasional dan internasional, munculnya paham feminis, serta telah meningkatnya partisipasi perempuan dalam politik dan pemerintahan telah mulai meredam stereotip yang buruk terhadap perempuan.

Saat ini terjadi ketimpangan antara jumlah akuntan profesional di Indonesia khususnya akuntan publik yang dibutuhkan dengan jumlah akuntan yang tersedia. Akuntan profesional yang tersedia pun di dominasi oleh akuntan yang telah berusia lebih dari 50 tahun dan berjenis kelamin laki-laki. Padahal jumlah mahasiswi akuntansi yang berjenis kelamin perempuan lebih banyak jika dibandingkan dengan mahasiswa berjenis kelamin laki-laki di dalam Perguruan Tinggi (Wirawan, 2017). Hal ini menunjukkan bahwa hanya sedikit mahasiswi akuntansi yang berminat melanjutkan karirnya menjadi akuntan profesional, khususnya akuntan publik/auditor. Ernawati dan Wibowo (2004) menjelaskan bahwa gender dapat mempengaruhi keputusan seorang mahasiswa untuk melanjutkan karir menjadi akuntan profesional. Dalam penelitian tersebut dijelaskan bahwa perempuan memiliki motivasi yang lebih rendah untuk melanjutkan karir menjadi akuntan profesional dari pada laki-laki.

\section{Penelitian Terdahulu}

Kuasirikun (2011) melakukan penelitian terhadap foto yang terdapat dalam laporan tahunan (апnиal report) perusahaan-perusahaan di Thailand. Penelitian tersebut bertujuan untuk memahami bagaimana gender dapat tergambarkan melalui foto dalam laporan tahunan perusahaan. Pauli (2016) melakukan penelitian tentang penggambaran gender dalam laporan tahunan perusahaan-perusahaaan real estate di Swedia. Penelitian dilakukan di perusahaan real estate karena perusahaan real estate merupakan perusahaan yang umumnya didominasi oleh lakilaki di Swedia. Pauli mengungkap bahwa laki-laki yang sedang sendirian digambarkan sebagai seorang karyawan di perusahaan sedangkan saat laki-laki dan perempuan ditampilkan bersamaan dalam stereotip posisinya masing-masing. Perempuan yang sendirian digambarkan mengisi posisi token. Pauli melakukan penelitian dengan menganalisis foto yang ada laporan tahunan perusahaan real estate dengan beberapa tahapan metode.

Untuk penelitian penggambaran gender di Indonesia masih tergolong sangat terbatas. Husna (2017) dan Myzad (2017) melakukan penelitian dengan menganalisis gambar dan foto yang terdapat pada laporan tahunan pada bank syariah di Indonesia. Penelitian yang mengalisis gender pada foto atau gambar melalui website resmi Institusi Profesional Akuntan tergolong penelitian yang baru. Kyriacou (2016) melakukan analisis gender melalui gambar atau foto pada website resmi Institusi Profesional Akuntan Yunani (SOEL) dengan menggunakan pendekatan Critical Discourse Analysis (CDA). Kyriacou (2016) menemukan bahwa perempuan lebih sedikit direpresentasikan pada website SOEL dari pada laki-laki. Hal ini tidak sesuai dengan realitas SOEL yang mendukung kesetaraan gender sebagai agenda utama, namun Kyriacou (2016) beragumen bahwa adanya peningkatan penggambaran perempuan pada website menjadi sinyal positif bagi partisipasi perempuan dalam profesi akuntan di Yunani. 


\section{Kerangka Konseptual}

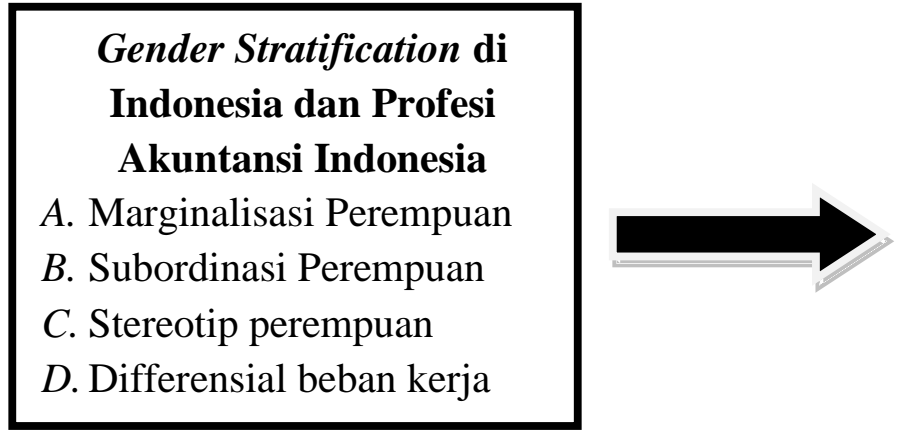

\section{Pesan yang tersampaikan melalui Foto}

a. Laki-laki secara dominan menempati jabatan yang lebih tinggi daripada perempuan.

b. Laki-laki lebih dominan menjadi pembicara/ pemateri dalam sebuah kegiatan daripada perempuan.

c. Laki-laki secara lebih dominan direpresentasikan sebagai sosok profesional daripada perempuan.

d. Laki-laki secara dominan berpartisipasi dalam sebuah forum/ kegiatan daripada perempuan.

\section{METODE PENELITIAN}

Metode yang digunakan dalam penelitian ini adalah deskriptif kualitatif karena peneliti ingin menggambarkan atau melukiskan keadaan atau fakta-fakta atau pun gejala yang terindikasi dalam website dan publikasi digital Ikatan Akuntan Indonesia (IAI). Penelitian deskriptif kualitatif berusaha untuk mendeskripsikan keseluruhan gejala atau keadaan yang ada, yaitu gejala atau keadaan menurut apa adanya pada saat penelitian tersebut dilakukan (Mukhtar, 2013:).

Jenis data yang digunakan dalam penelitian ini adalah data sekunder. Dalam penelitian ini data sekunder diperoleh dari website resmi Ikatan Akuntan Indonesia (IAI) www.iaiglobal.or.id, data yang peneliti maksud adalah berupa gambar-gambar yang tersedia di dalam website IAI lebih spesifiknya pada Materi dan Publikasi, Berita dan Kegiatan, serta Kepengurusan IAI. Gambar yang akan menjadi objek penelitian ini adalah gambar yang dipublikasi pada rentang tahun 2016-2018. Metode yang digunakan untuk mengumpulkan data dalam penelitian ini adalah metode dokumentasi dengan mengumpulkan yang tertulis dan berhubungan dengan masalah penelitian yaitu representasi gender.

\section{HASIL DAN PEMBAHASAN Gambaran Kuantitatif}

Analisis kuantitatif dari gambar dalam website Ikatan Akuntan Indoneesia (IAI) menunjukkan bahwa gambar yang ditampilkan dalam website didominasi oleh gambar manusia dan sebagian kecil merupakan gambar bukan manusia. Hal ini terlihat dari total representasi gambar manusia sebesar 76,8\% dan gambar bukan manusia sebesar 23,2\% pada tahun 20162018. Gambar manusia ditampilkan dalam website Ikatan Akuntan Indonesia sebesar 61,5\% (2016), 36,4\% (2017), dan 76,8\% (2018) dari gambar yang ada dalam website. Gambar bukan manusia ditampilkan dalam website sebesar 38,5\% (2016), 63,6\% (2017), dan 12\% (2018). 


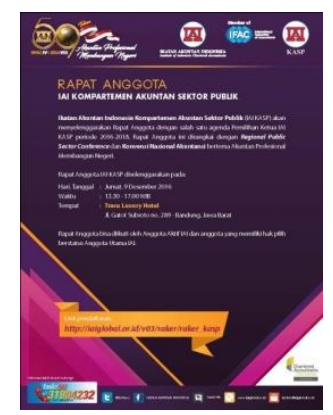

Gambar 1. Undangan Rapat Anggota (2016)

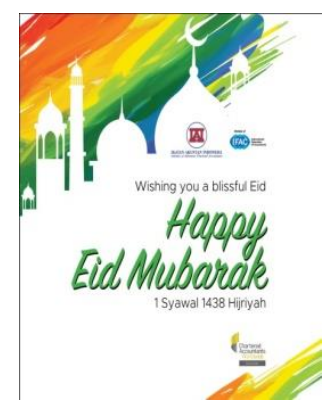

Gambar 2. Ucapan Idul Fitri (2017)

Berdasarkan uraian tersebut dapat diketahui bahwa gambar manusia yang ada dalam website Ikatan Akuntan Indonesia mendominasi pada tahun 2016 dan 2018. Sedangkan pada tahun 2017, gambar bukan manusia lebih mendominasi daripada gambar manusia.

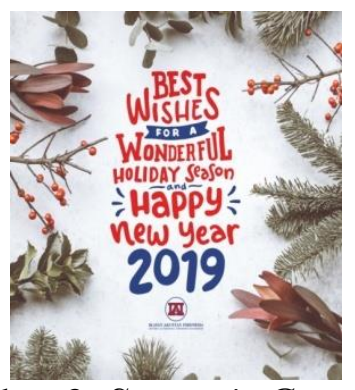

Gambar 3. Season's Greetings

Setelah melakukan eksplorasi, ditemukan bahwa gambar bukan manusia terdiri dari brosur/pamflet kegiatan (seminar, undangan rapat, konferensi, kongres), gambar palu, Season's Greeting, Ucapan Idul Fitri, dan lainnya. Gambar 1, 2, dan 3 merupakan contoh gambar bukan manusia yang terdapat dalam website Ikatan Akuntan Indonesia. Analisis kuantitatif terkait penggambaran gender dari gambar dalam website Ikatan Akuntan Indonesia (IAI) pada tahun 2016-2018 menunjukkan bahwa gambar yang ditampilkan didominasi oleh gambar Laki-Laki dengan total persentase sebesar 46,5\%, kemudian laki-laki dan perempuan bersama sebesar $34,9 \%$, dan sebagian kecil merupakan gambar perempuan dengan persentase 18,6\%. Secara lebih spesifik gambar yang ditampilkan didominasi oleh laki-laki sendiri dengan persentase $37,25 \%$, kemudian secara berurutan disusul oleh laki-laki dan perempuan bersama sebesar $34,9 \%$, perempuan sendiri $16,3 \%$, laki-laki berkelompok $9,3 \%$, dan perempuan sendiri $2,3 \%$. 
Berdasarkan uraian tersebut dapat diketahui bahwa dalam website Ikatan Akuntan Indonesia menampilkan gambar laki-laki dengan jumlah persentase yang lebih besar. Sedangkan gambar campuran dan perempuan ditampilkan dalam persentase yang lebih sedikit dibandingkan gambar laki-laki. Secara detail gambar laki-laki lebih ditampilkan dengan persentase yang lebih besar pada tahun 2016 dan 2018, sedangkan pada tahun 2017 gambar laki-laki ditampilkan dengan jumlah yang sama dengan gambar perempuan.

\section{Interpretasi Hasil Penelitian}

\section{a. Gender Sebagai Profesional}

Analisis kuantitatif awal terkait gambar profesional dan bukan profesional dalam website Ikatan Akuntan Indonesia (IAI) pada tahun 2016-2018. Gambar yang ditampilkan didominasi oleh gambar Laki-Laki profesional dengan total persentase sebesar $71 \%$, sedangkan gambar perempuan profesional ditampilkan dengan persentase jauh lebih sedikit yaitu sebesar $29 \%$. Selisih dengan jumlah yang sangat signifikan ini sesuai dengan stereotip yang terdapat di masyarakat Indonesia yaitu laki-laki dianggap merupakan sosok yang lebih profesional dalam dunia pekerjaan maupun profesi dibandingkan dengan perempuan. Untuk perincian setiap tahunnya, laki-laki ditampilan sebagai sosok profesional mendominasi pada tahun 2016 dan 2018 sebesar 73\%, sedangkan perempuan profesional hanya mendominasi pada tahun 2017 yaitu sebesar $60 \%$.

Selain itu tidak adanya penggambaran laki-laki atau perempuan sebagai sosok yang tidak profesional dalam website Ikatan Akuntan Indonesia. Ini menunjukkan bahwa IAI berfokus pada penggambaran laki-laki atau perempuan sebagai sosok yang sama-sama profesional, meskipun dari segi kuantitas penggambaran laki-laki sebagai profesional masih lebih dominan secara keseluruhan. Selain itu, dapat ditarik makna implisit bahwa IAI telah berusaha untuk meredam stereotip yang berkembang di masyarakat yaitu bahwa perempuan bukanlah sosok yang profesional dalam pekerjaan atau profesi dengan cara tidak menampilkan gambar perempuan sebagai sosok yang tidak profesional. Selain itu adanya upaya untuk menampilkan pesan bahwa perempuan memiliki tingkat profesionalitas yang sama atau bahkan lebih tinggi daripada lakilaki dengan cara menampilkan gambar dominasi perempuan sebagai sosok yang profesional dalam pekerjaan atau profesi meskipun hanya satu tahun.

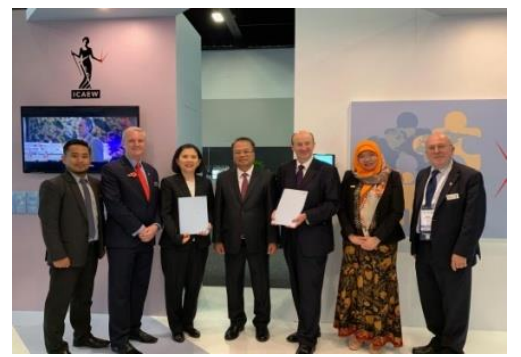

Gambar 4. MoU IAI \& ICAEW (2018) 


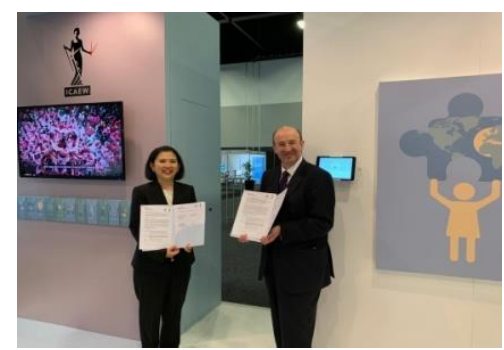

Gambar 5. MoU IAI \& ICAEW (2018)

Dari gambar 4 tersebut dapat dilihat bahwa keseluruhan pihak digambarkan begitu profesional dengan menggunakan pakaian yang formal dan berada dalam pertemuan yang resmi. Dalam gambar 4 ini dapat dilihat bahwa laki-laki mendominasi unsur gambar, terdapat dua empat orang laki-laki ditampilkan secara profesional, serta dua orang lainnya adalah perempuan profesional.

Pada gambar 5 laki-laki dan perempuan secara profesional dengan jumlah yang berimbang yaitu masing-masing satu orang. Dari kedua gambar tersebut dapat ditangkap isyarat bahwa perempuan juga merupakan sosok yang profesional dalam pekerjaan atau profesi, begitu halnya dengan laki-laki. Meskipun stereotip yang berkembang di Indonesia perempuan merupakan sosok yang kurang profesional dalam pekerjaan atau profesi dan mengalami kesulitan untuk memasuki profesi.

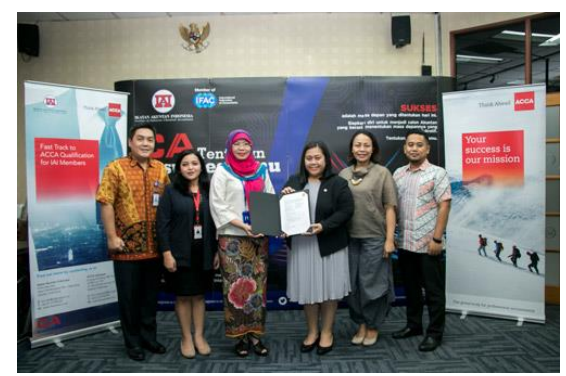

Gambar 6. IAI ACCA (2017)

Dalam gambar 6, terlihat bahwa perempuan mendominasi gambar dengan jumlah empat perempuan, sedangkan dua orang lainnya adalah laki-laki. Pesan yang tersampaikan adalah bahwa perempuan saat ini telah memiliki akses yang lebih luas untuk memasuki dunia profesi akuntansi. Hal ini sejalan dengan misi pemerintah dan IAI untuk membuka akses yang setara bagi perempuan dan laki-laki dalam dunia profesi dan menjadi profesional demi mencapai kesetaraan gender dalam profesi akuntansi.

\section{b. Gender Sebagai Speaker (Pembicara)}

Kita dapat memperhatikan apakah laki-laki atau perempuan mendominasi posisi audience dalam sebuah pertemuan profesional. Dalam hal ini, peneliti akan melihat dalam kedudukan sebagai audience gender manakah yang paling mendominasi. 


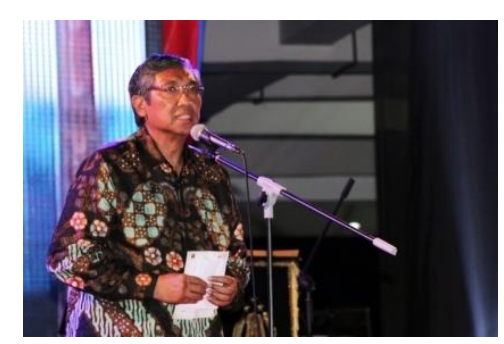

Gambar 7. Anniversary IAI ke 60 (2016)

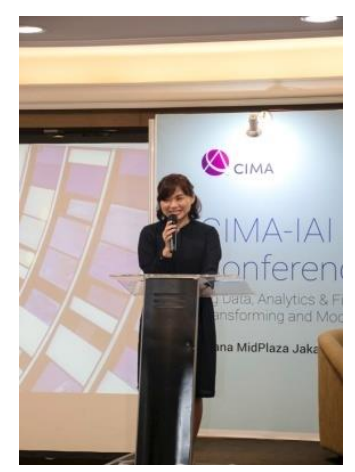

Gambar 8. IAI-CIMA Regional Joint Conference (2018)

Terlihat pada gambar 7, Ketua IAI, Prof. Mardiasmo sendiri berdiri di podium sedang memberikan pidato. Pada gambar 8, terlihat Kepala Regional CIMA SEA yaitu Ms. Ginny Lim, berdiri sendiri di podium dan memberikan pidato. Dalam kegiatan ini Ikatan Akuntan Indonesia (IAI) bekerja sama dengan Chartered Institute of Management Accountants (CIMA). Tujuan utama dari kegiatan ini adalah untuk memberikan masukan kepada akuntan profesional dalam industri digital.

Dari kedua gambar tersebut, dapat ditarik makna bahwa laki-laki maupun perempuan memiliki peluang dan peranan yang sama dalam menjadi pembicara utama dalam sebuah forum/kegiatan. Hal ini merupakan sebuah kemajuan, dimana stereotip yang berkembang adalah perempuan merupakan peserta pasif dan cenderung tidak bisa melakukan apa yang bisa laki-laki lakukan, termasuk dalam menjadi pembicara/pemateri sebuah kegiatan. Adanya perempuan melalui penggambaran ini, menjadi sinyal positif dalam profesi akuntansi dalam hal kesetaraan gender dimana laki-laki dan perempuan telah memiliki kemampuan dan kesempatan yang sama untuk menjadi bagian penting dalam profesi akuntansi terkhusunya dalam kegiatan ini.

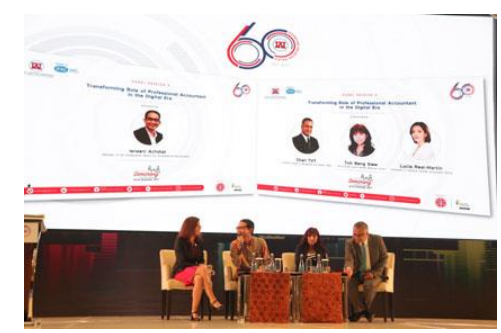

Gambar 9. Anniversary IAI ke 60 (2018)

Gambar 9 menampilkan kesetaraan jumlah laki-laki dan perempuan yang menjadi pemateri dalam kegiatan seminar Internasional. Gambar ini dapat menjadi sebuah kesimpulan bahwa dalam Ikatan Akuntan Indonesia, perempuan telah dianggap setara dengan laki-laki dalam 
segi kompetensi. Dalam proses eksplorasi website IAI, ditemukan bahwa hampir dalam setiap kegiatan yang membutuhkan pemateri/pembicara, perempuan selalu berpartisipasi menjadi pemateri/pembicara utama dan dalam segi kuantitas jumlahnya hampir sama atau bahkan sama dengan jumlah laki-laki. Ini meerupakan sebuah langkah positif bagi IAI dan profesi akuntansi dalam hal kesetaraan gender. IAI telah berusaha meredam stereotip atau stigma yang ada di masyarakat bahwa perempuan memiliki kedudukan dan kualitas yang lebih rendah dalam pekerjaan dibandingkan dengan laki-laki. Namun, pada IAI stereotip atai stigma tersebut tidak berlaku.

\section{c. Gender Sebagai Audience}

Analisis peran audience ini difokuskan kepada bagaimana perempuan dan laki-laki ditampilkan sebagai pendengar pada gambar dalam webiste. Kita akan melihat bagaimana perempuan dan laki-laki berinteraksi dalam gambar yang disajikan.

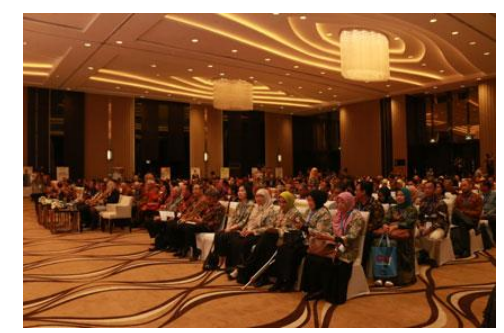

Gambar 10. Seminar Internasional (2018)

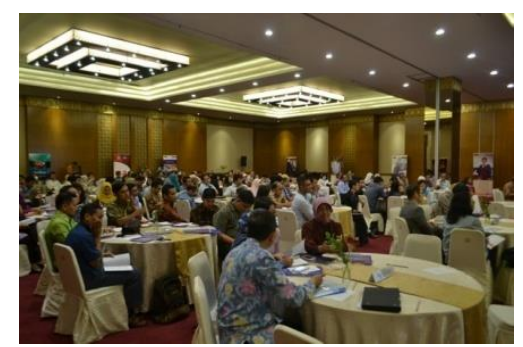

Gambar 11. Press Release (2016)

Dalam website IAI terdapat gambar-gambar yang memperlihatkan perempuan menjadi pemateri/pembicara utama dalam sebuah kegiatan, baik berdiri sendiri di podium atau bersama dengan para pembicara lainnya. Hal ini menepis stereotip yang berkembang di masyarakat bahwa perempuan biasanya hanya menjadi audience pasif, dan memiliki peran sebagai pendengar, pendukung, dan pemerhati terhadap laki-laki. Namun berdasarkan gambar 11 dan 12, terlihat yang menjadi audience tidak hanya perempuan melainkan laki-laki juga dan tidak terdapat perbedaan kuantitas yang begitu signifikan. Dalam kedua gambar tersebut terlihat perempuan maupun laki-laki duduk bersama tanpa adanya pemisahan tertentu yang mengindikasikan bahwa perempuan dan laki-laki telah memiliki sinergi yang baik dalam menjadi audience.

Selain itu, terdapat istilah audience pasif dan audiemce pasif. Dalam setiap pertemuan yang diadakan Ikatan Akuntan Indonesia, audience laki-laki dan perempuan dapat diindikasikan merupakan audience aktif. Tolak ukurnya adalah dinamika kegiatan dan keterlibatan pihak audience. Dinamika kegiatan berjalan aktif, karena audience akan merespon speaker secara gestur seperti fokus dalam menyimak, mengangguk, menulis, tepuk tangan maupun melontarkan 
pertanyaan nantinya pada sesi yang telah disediakan. Selain itu, dalam hal keterlibatan audience, pada umumnya baik speaker maupun audience pertemuan atau forum ini merupakan bagian dari Ikatan Akuntan Indonesia yang memiliki latar belakang pendidikan yang tinggi dan memiliki spesialisasi pada akuntansi. Tentu saja, audience tersebut memiliki keterlibatan yang tinggi tidak hanya dalam pertemuan, melainkan diluar pertemuan karena para audience pada nantinya akan menjalankan program-program yang telah diinisasi diawal kepengurusan atau program-program yang diinisiasi pada saat pertemuan/forum.

\section{d. Gender Dalam Sebuah Forum/Pertemuan \\ Peran}

Dokumentasi dalam sebuah forum atau pertemuan dapat mengindikasikan peranan penting gender dalam pertemuan tersebut. Apakah organisasi menggambarkan secara seimbang atau malah adanya dominasi penggambaran gender dalam sebuah forum atau pertemuan tersebut dari segi kuantitas gambar yang disajikan organisasi dalam website.

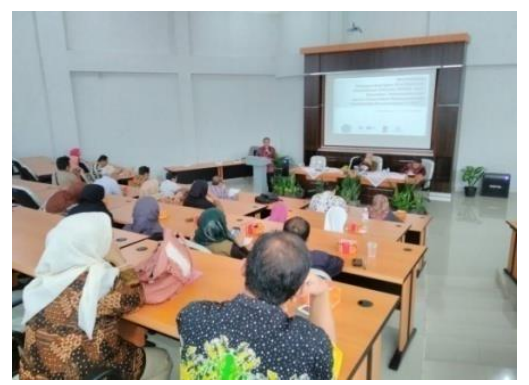

Gambar 12. Pengembangan Kurikulum Akuntansi (2018)

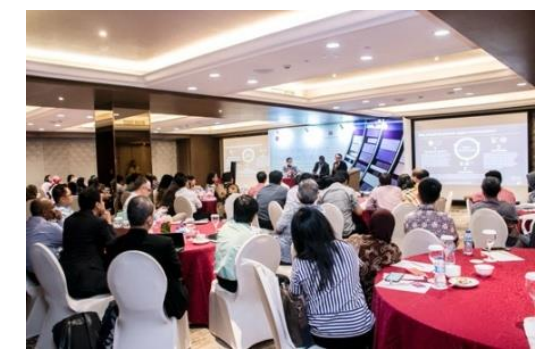

Gambar 13. CIMA Regional (2018)

Pada gambar 12 dan 13 terlihat kegiatan pertemuan/forum yang melibatkan pembicara dan audience. Dalam gambar tersebut tidak terlihat dominansi gender tertentu. Laki-laki maupun perempuan terlihat dalam jumlah yang berimbang dan memiliki peran yang berimbang baik menjadi pembicara dan audience meskipun terdapat berbagai stereotip yang menyebabkan perempuan menjadi kelompok yang minoritas dalam sebuah pekerjaan atau profesi contohnya glass ceiling dan perempuan lebih cocok menjadi ibu rumah tangga. Ini menjadi isyarat positif bahwa Ikatan Akuntan Indonesia terutama profesi akuntansi telah menuju proses kesetaraan gender. 


\section{1) Persetujuan Kesepakatan}

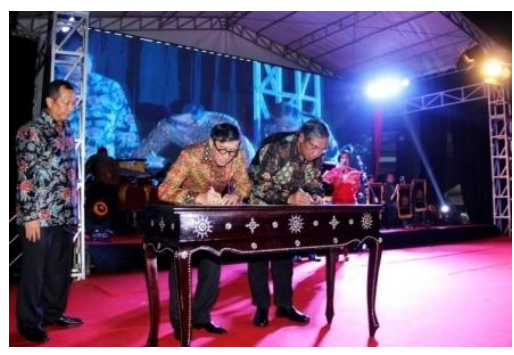

Gambar 14. Penandatanganan Kesepakatan (2016)

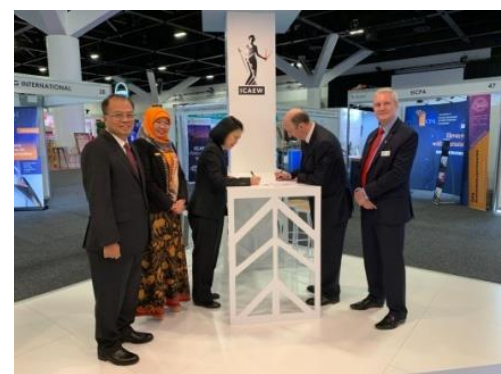

Gambar 15. Penandatangan Kesepakatan (2018)

Kesepakatan merupakan unsur penting dalam sebuah kerjasama, tentu saja orang yang akan dipilih untuk mewakili organisasi dalam hal penandatangan atau persetujuan kesepakatan ini adalah orang yang memiliki rasionalitas yang tinggi dan sangat paham akan visi dan misi organisasi. Lazimnya, stereotip yang ada di masyarakat adalah laki-laki merupakan sosok yang lebih rasional dibandingkan dengan perempuan, sedangkan perempuan merupakan sosok yang kurang rasional dan lebih mengutamakan emosional dalam pengambilan keputusan.

Pada gambar 14 terlihat orang yang mewakili penandatanganan kesepakatan yang mewakili IAI adalah laki-laki, sedangkan pada gambar 15, orang yang mewakili proses penandatanganan adalah perempuan. Ini menunjukkan bahwa IAI mengakui bahwa rasionalitas tidak lagi bergantung pada gender seseorang. Laki-laki maupun perempuan memiliki rasionalitas yang relatif sama dalam pengambilan keputusan yang berkenaan dengan profesi atau organisasi.

\section{2) Posisi Relatif}

Gambar menampilkan kedua jenis kelamin memungkinkan kita untuk membandingkan posisi fisik pria dan wanita. Contohnya beberapa foto pria mengambil posisi fisik yang lebih tinggi dari pada perempuan: misalnya pria berdiri sementara wanita duduk atau sebaliknya. Posisi relatif fisik yang lebih tinggi atau lebih besar melambangkan posisi sosial yang lebih tinggi, posisi lebih rendah melambangkan penyerahan. Dengan perbedaan visual dalam posisi fisik, memperkuat stereotip klasik maskulinitas dan feminitas.

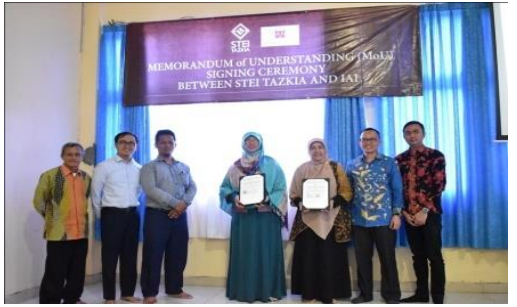

Gambar 16. IAI dan Tazkia (2018) 


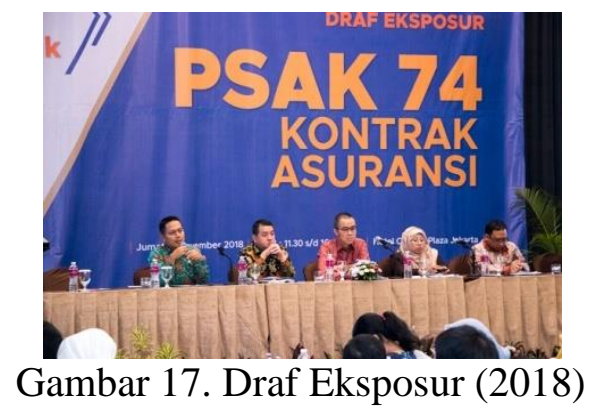

Jika dilihat pada gambar 16, posisi relatif laki-laki dan perempuan adalah sama-sama berdiri (tinggi). Pada gambar 17, posisi relatif laki-laki dan perempuan adalah sama-sama duduk (rendah). Hal ini menunjukkan bahwa Ikatan Akuntan Indonesia melambangkan laki-laki dan perempuan memiliki posisi sosial yang setara. Dalam website IAI apabila laki-laki dan perempuan bersama kebanyakan digambarkan bersama-sama berdiri atau duduk. Ini merupakan suatu bentuk upaya untuk mencapai tingkat kesetaraan gender yang di ideal, dengan tidak membedakan posisi relatif laki-laki dan perempuan.

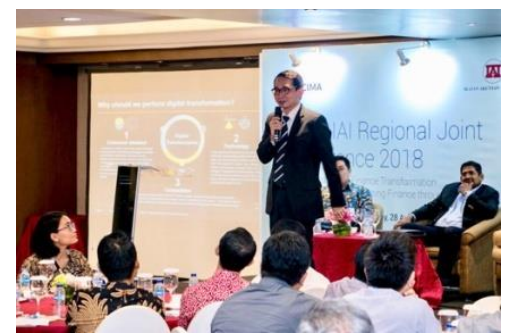

Gambar 17. Seminar Internasional (2018)

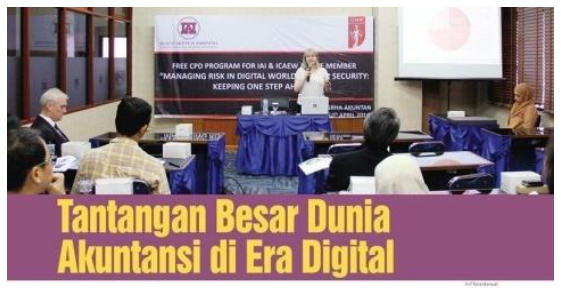

Gambar 18. IAI 2018)

Pada gambar 17, terlihat seorang laki-laki mengambil posisi relatif yang lebih tinggi (berdiri) dari pada laki-laki dan perempuan yang lain (duduk). Sedangkan pada gambar 18, seorang perempuan mengambil posisi relatif yang tinggi dari pada perempuan dan laki-laki yang lain. Jika ditarik makna yang mendalam, ini merupakan sebuah penggambaran yang sangat bagus. Dimana IAI mencoba untuk menyampaikan pesan bahwa setiap individu terlepas dari gender yang ia miliki, memiliki peluang yang sama untuk meningkatkan posisi sosial masingmasing dalam profesi atau masyarakat. Hal itu tergantung pada kompetensi dan usaha yang dilakukan, profesi telah membuka akses yang setara bagi setiap individu untuk menjadi profesional.

\section{e. Gender Dalam Kepengurusan}

Analisis dalam kepengurusan ini difokuskan kepada bagaimana perempuan dan laki-laki ditampilkan sebagai bagian dari kepengurusan Ikatan Akuntan Indonesia pada gambar dalam 
webiste. Kita akan melihat bagaimana persentase struktur kepengurusan. Apakah terdapat perempuan dalam struktur kepengurusan meskipun terdapat stereotip yang menghambat perempuan memasuki dunia profesi dan menjadi pemimpin dalam profesi tersebut.

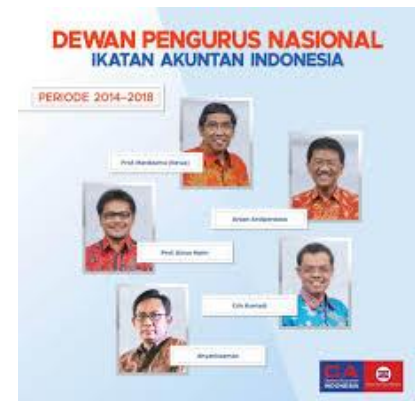

Gambar 19. Dewan Pengurus Nasional IAI 2014-2018

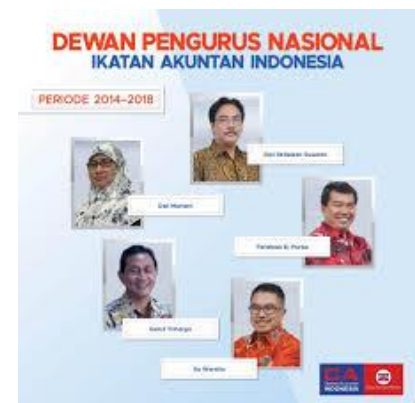

Gambar 20. Dewan Pengurus Nasional IAI 2014-2018

Gambar 19 dan 20 merupakan gambar jajaran Dewan Pengurus Nasional Ikatan Akuntan Indonesia yang ditampilkan dalam website pada periode 2014-2018. Dalam gambar ini dapat dilihat bahwa dalam posisi tinggi ini salah satu dari sepuluh dewan pengurus nasional adalah perempuan. Ini berarti persentase gperempuan adalah sebesar 10\% dan laki-laki adalah $90 \%$.

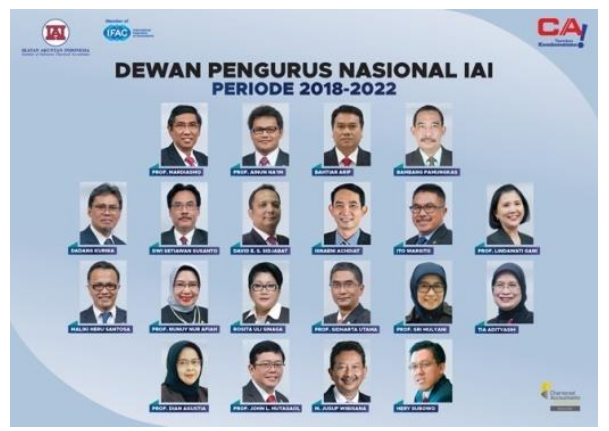

Gambar 21. Dewan Pengurus Nasional IAI 2018-2022

Gambar 21 merupakan gambar jajaran Dewan Pengurus Nasional Ikatan Akuntan Indonesia yang ditampilkan dalam website pada periode 2018-2022. Dalam gambar ini dapat dilihat bahwa dalam posisi ini terdapat 20 orang, dan jumlah ini lebih banyak dari Dewan Pengurus Nasional periode sebelumnya. Enam dari dua puluh dewan pengurus nasional adalah perempuan. Ini berarti persentase perempuan adalah sebesar 30\% dan laki-laki adalah 70\%. Gambar-gambar tersebut menunjukkan bahwa terdapatnya peningkatan persentase keterlibatan 
perempuan dalam Dewan Pengurus Nasional IAI yang sebelumnya hanya $10 \%$ meningkat menjadi 30\%. Terlebih gambar-gambar tersebut juga menjelaskan bahwa di Ikatan Akuntan Indonesia perempuan mempunyai kesempatan untuk menempati posisi yang tinggi sama seperti laki-laki yaitu sebagai seorang pemimpin dalam bagian yang ada profesi. Meskipun stereotip yang berkembang di Indonesia bahwa perempuan adalah seseorang yang harus bertanggung jawab untuk mengurus keluarga sehingga sangat sulit untuk dapat berkarir lebih tinggi.

\section{SIMPULAN, KETERBATASAN, DAN SARAN \\ Simpulan}

1. Gambaran kuantitatif menunjukkan bahwa penggambaran gender dalam website tidak mendorong kesetaraan antara laki-laki dan perempuan dalam profesi. Hal ini sesuai dengan stereotip yang berkembang di Indonesia bahwa yang bekerja itu seharusnya adalah laki-laki.

2. Analisis gender sebagai profesional yang dilakukan pada gambar yang ada dalam website menunjukkan bahwa dalam gambaran kuantitatif ditemukan perbedaan antara penggambaran yang cukup signifikan antara laki-laki dan perempuan. Laki-laki lebih sering muncul sebagai sosok yang profesional dari pada perempuan. Namun yang menjadi poin positif adalah $100 \%$ laki-laki dan perempuan digambarkan sebagai sosok yang profesional, tidak adanya penggambaran sebagai sosok yang tidak profesional. Kesimpulan kedua poin tersebut adalah adanya kesesuaian dengan stereotip dimana laki-laki dianggap lebih profesional dalam dunia profesi dari pada perempuan. Namun, disisi lain IAI coba untuk menggambarkan bahwa perempuan juga merupakan sosok yang profesional dalam sebuah profesi.

\section{Keterbatasan}

Penelitian ini tergolong penelitian baru yang membahas aspek kualitatif berupa gambar dalam website. Penelitian ini berupa retorika yang bertujuan mengubah pandangan pengguna website tentang pentingnya aspek gambar dalam website. Hasil analisis dalam penelitian ini mengandung unsur subjektivitas yang cukup tinggi. Hal tersebut dikarenakan metode yang digunakan dalam menganalisis content visual atas elit bisnis yang disajikan dalam website perusahaan. Selain itu, belum adanya standar yang mengatur bagaimana pengungkapan gambar di dalam website, akan menambah kesulitan dalam membuat interpretasi

\section{Saran}

Berdasarkan hasil penelitian yang sudah diperoleh, maka peneliti menyarankan peneliti selanjutnya untuk meneliti website atau laporan tahunan perusahaan/organisasi profesi yang berbeda dari penelitian ini serta dalam rentang tahun yang lebih luas. Selain itu, Peneliti selanjutnya diharapkan mampu mengangkat aspek kualitatif lain seperti linguistik atau semiotika yang terdapat dalam website atau laporan tahunan yang dapat memberikan hasil analisis dan pemahaman yang lebih spesifik serta berkualitas mengenai gender pada perusahaan atau organisasi profesi.

\section{DAFTAR PUSTAKA}

Adams, Renee B. \& Ferreira, Daniel. (2009). Women In The Boardroom And Their Impact On Governance And Performance. Journal of Financial Economic, 94,291-309.

Adler, P.S., Kwon, S.W., \& Heckscher, Charles. Professional Work: The Emergence Collaboratiive Community. Organization Science, 19, 359-376. 
Agustianto, Angga. (2013). Pengaruh Profesionalisme, Pengalaman Auditor, Gender Dan Kualitas Audit Terhadap Pertimbangan Tingkat Materialitas Dalam Proses Pengauditan Laporan Keuangan. Skripsi. Jakarta: Universitas Islam Negeri Syarif Kasim Hidayatullah Jakarta.

Andon, P. \& Chen, C. (2011). Combining creativity and control: Understanding Individual Motivation In Large Scale Collaborative Creativity. Accounting, Organization, and Society, 36, 63-85.

Appadurai, A. (1996). Modernity at large : Cultural Dimention of Globalization. University of Minesstota Press, Minneapolis, MN.

Baldo, D.M., Tiron, T.A., \& Faragalla, W.A. (2018). Women's Role In The Accounting Profession: A Comparative Study Between Italy And Romania. Administrative Science.

Ballantine, J. \& mccourt, P. (2011). The Impact Of Ethical Orientation And Gender On Final Year Undergraduate Auditing Students Ethical Judgement. Accounting Education: an international journal, 20, 87-201.

Baxter, Janeen \& Erik, O.W. (2000). The Glass Ceiling Hypothesis: A Comparative Study of The United States, Sweden, and Australia. Gender and Society, 14,275-294.

Belkaoui, Ahmed. (1980). The Impact of Socio-Economic Accounting Statements on The Investment Decision : An Empirical Study. Econpapers, 3, 263-283.

Bell, Myrtle P., McLaughlin, Mary E., \& Sequira, Jennifer M. (2002). Discrimination, harassment, and the glass ceiling: Women executives as change agents. Journal of Bussiness Ethics: 37,65-76.

Benschop, Y \& Meihuizen, HE. (2002). Keeping Up Gendered Appearance: Representations Of Gender In Annual Reports. Accounting, Organizations and Society, 27,611-636.

Borgia, C. R., \& Shrager, B. E. (2000). International opportunities for smaller CPA firms on the internet. CPA Journal, 70, 67-68.

Brinton, Mary C. (1998). The Social-Institutional Bases Of Gender Stratification: Japan As An Illustrative Case. American Journal of Sociology, 94,300-334.

Broadbent, Jane \& Kirkham, Linda. (2008). Glass Ceilings, Glass Cliffs Or New Worlds?: Revisiting Gender And Accounting. Accounting and Accountability Journal, 21,465-43.

Bryant, Lydia L. (2010). What Role Does 'Glass Ceiling' Play For Women In The Accounting?. The York Scholar, 1,2-13.

Budiartie, Gustidha. (2019). Jika wanita tak diberi peluang, betapa banyak kesia-siaan. CNBC Indonesia.

Chapman, P. \& Peecher, M. (2011). World of assurance. Accounting, Organzation, and Society, 36,267-268.

Chou, W. C., \& Cheng, Y. P. (2012). A hybrid Fuzzy MCDM approach for evaluating website quality of accounting firms. Expert Systems With Applications, 39, 2783-2793.

Collins, Randal. (1990). Conflict Theory and the advance of macro-historical sociology. In Frontiers of Social Theory. Edited by George Ritzer. New York: Columbia University Press, pp.68-87.

Collins, Randal., Chafetz, S.J., Blumberg, R.L., Coltrane, Scott., and Turner, J.H. (1993). Toward an Integrated theory of Gender Stratification. Sociological Perspectives, 36,185216.

Cooper, D. \& Morgan, W. (2013). Meeting The Evolving Corporate Reporting Needs Of Government And Society: Arguments For A Deliberative Approach To Accounting Rule Making. Accounting and Bussiness Research, 43,418-441. 
Damrin, C. \& Lambert, C. (2012). Who Is She And Who Are We? A Reflexive Journey In Research Into The Rarity Of Women In The Highest Rank Of Accountancy. Critical Perspective on Accounting. Elsevier, 23,1-16.

Davison J. (2007). Photograph and accountability: cracking the codes of an NGO. Accounting,Auditing, and Accountability Journal, 20,133-158.

Davison J. (2010). [In]visible [in]tangibles: Visual portraits of the business élite. Accounting, Organizations, and Society, 35,165-183.

Dzulasri, Warisya. (2018). Pengaruh Budaya dan Gender Terhadap Keputusan Akuntan. Skripsi. Fakultas Ekonomi. Universitas Neger Padang : Padang.

Emzir. (2012). Metodologi Penelitian Kualitatif: Analisis Data. Jakarta: Rajawali Pers.

Ernawati \& Wibowo, Edi. (2004). Pengaruh Gender Terhadap Keinginan Mahasiswa Akuntansi Dalam Memilih Profesi Akuntan Publik Dan Non Akuntan Publik. Jurnal Ekonomi dan Kewirausahaan, 4,56-65.

Hans Katikahadi, et al. (2012). Akuntansi Keuangan Berdasarkan SAK berbasis IFRS. Jakarta: Salemba Empat.

Hans, Joas. \& Wolfgang, Knobl. (Ed). (2011). Conflict sociology and conflict theory. In Social Theory: Twenty Introductory Lectures. Cambridge: Cambride University Press, 174-198.

Heinz, P., Patel, C., \& Hellman, A. (2013). Some Theoretical And Methodological Suggestions For Studies Examining Accountants Professional Judgments And Earning Management. Advances in Accounting, incorporating Advances inv International Accounting.

Hellman, M., Wagnsson, C. (2013). New Media And The War In Afghanistan: The Significant of Blogging For The Sweddish Strategic Narrative. New Media and Society.

Husna, Fajriatul. (2017). Analisis Representasi Gender Dalam Laporan Tahunan Bank Syariah Indonesia 2013-2015. Skripsi. Fakultas Ekonomi. Universitas Neger Padang : Padang.

Ida, Rachmah. (2014). Metode Penelitian Studi Media dan Kajian Budaya. Jakarta: Prenada Media Group.

ILO. (2015). Tren Ketenagakerjaan dan Sosial di Indonesia 2014-2015: Memperkuat Daya Saing dan Produktivitas Melalui Pekerjaan Layak. Jakarta: Kantor Perburuhan Internasional.

Ikatan Akuntan Indonesia. (2020). Diakses dari www.iaiglobal.or.id

Jeacle, Ingrid \& Carter, Christ. (2014). Creative Spaces In Interdisciplinary Accounting Research. Accounting, Auditing \& Accountability Journal, 27,1233-1240.

Kamla, Rania. (2012). Syrian Women Accountants Attitudes And Experiences At Work In The Context Of Globalization. Accounting, Organizations and Society, 37,188-205.

Kamla, Rania \& Roberts, Clare. (2010). The global and the local: Arabian Gulf States And Imagery In Annual Reports. Accounting, Auditing \& Accountability Journal, 23,449-481.

Karpov, Dmitry \& Kryuchkov, Yuriy. (2015). Analytical Photography as New Tool For Representations of Reality. Procedia - Social and Behavioral Sciences, 166,675-679.

Kasmir. (2012). Dasar-dasar Perbankan. Jakarta: Rajawali Pers.

Keister, L.A. \& Southgate, D.E. (2012). Inequality: A Contemporary Approach to Race, Class, and Gender. Cambridge: Cambridge University Press.

Kementerian Pemberdayaan Perempuan Dan Perlindungan Anak. (2020). Diakses dari www.kemenpppa.go.id

Kuasirikun, Nooch. 2011. The Portayal Of Gender In Annual Reports In Thailand. Critical Perspectives On Accounting, 22(2011) 53-78. 
Kusuma, U.D. 2019. Praktik Diskriminasi Perempuan Masih Banyak. CNN Indonesia.

Kusuma, Hendra. (2019). Tak Atasi Kesetaraan Gender, RI Berpotensi Kehilangan US\$135 M. Detik Finance.

Kyriacou, Orthodoxia. (2016). Accounting For Images Of 'Equality’ In Digital Space: Towards An Exploration Of The Greek Accounting Professional Institute. Critical Perspective On Accounting, 35,35-37.

Kyriakidou, Olivia, Kyriachou, O., Ozbilgin, M., \& Dedoulis, E. (2013). Equality, Diversity, and Inclusion in Accounting. Critical Perspective on Accounting. Special Issue, 35,1-12.

Lindawati \& Smark, Ciorstan. (2010). Education into employment? Indonesian and Moving from Business Education into Professional Partisipation. E-journal of Business Education \& Scholarship of Teaching, 4,29-42.

Litivin, S., Goldsmith, R., \& Pan, B. (2008). Electronic Word Of Mouth In Hospitality And Tourism Management. Tourism Management. 29,458-468.

Luthy, M. R., \& Carver, P. (2004). Accounting Firms In Cyberspace : A Critique Of The Big 4. Proceeding of the Academy of Accounting of Financial Studies, 9,53-59.

Mansour, Fakih. (2013). Analisis Gender dan Transformasi Sosial. Yogyakarta: Pustaka Pelajar.

Meyer, R. et. al. (2013). The Visual Dimension In Organizing, Organization, And Organization Research, Core Ideas, Current Developments, And Promosing Avenues. The Academy Of Management Annuals, 7,489-555

Mukhtar. (2013). Metode Praktis Penelitian Deskriptif Kualitatif. Jakarta Selatan: Referensi. GP Press Group.

Murtanto. (2003). Persepsi Akuntan Pria Dan Akuntan Wanita Serta Mahasiswa Dan Mahaasiswi Akuntansi Dipandang Dari Segi Gender Terhadap Etika Bisnis Dan Etika Profesi (Studi Di Wilayah Surakarta). Kumpulan Simposium Nasional Akuntansi IX. Padang.

Muzio, D., Kirkpatrick, I., \& Kipping, M. (2011). Professions, organizations, and the state: Applying the sociology of the profession to the case of management consultancy. Current Sociology.

Myzed, I.D. (2017). Analisis Realitas Gender Dalam Laporan Tahunan Perusahaan Di Indonesia (Studi Kasus Pada Beberapa Bank Syariah Tahun 2013-2015. Skripsi. Fakultas Ekonomi. Universitas Negeri Padang : Padang.

Nasrullah, Rulli. (2014). Teori dan Riset Media Siber. Jakarta: Kencana Prenadamedia Group.

Nazir, Muhammad, Ph.D (2011). Metode Penelitian. Jakarta: Ghalia Indonesia.

Kartini, Nurrahmah \& Muthmainah, Siti. (2013). Analisis Pengaruh Diversitas Gender Terhadap Voluntary Corporate Governance Disclosure dalam Laporan Tahunan Perusahaan. Diponegoro Journal Of Accounting.

Ritzer, G. \& Jurgenson, N. (2010). Production, Consumption, Presumption: The Nature Of Capitalism In The Age Of Digital Prosumer. Journal of Consumer Culture, 10,13-36.

Roxas, M. L., Peek, L., \& Peek, G. (2000). A Preliminary Evaluation Of Professional Accounting Services : Direct Marketing On The Internet. Journal of Service Marketing, 14, 595-606.

Sakina, A. I \& Siti, D. A. (2017). Menyoroti Budaya Patriarki di Indonesia. E-journal Universitas Padjajaran. 
Salsabila, Ainia \& Prayudiawam, Hepi. (2011). Pengaruh Akuntanbilitas, Pengetahuan Audit, Gender Terhadap Kualitas Hasil Kerja Auditor Internal. Jurnal Telaah \& Riset Akuntansi. 4,155-175.

Sari, A.S. (2014). Pengaruh Akuntanbilitas, Pengetahuan Audit, Gender, Dan Integritas Terhadap Kualitas Hasil Kerja Audit Internal. Skripsi Thesis. Riau: Universitas Islam Negeri Sultan Syarif Kasim.

Sarlito W.S. (2015). Psikologi Lintas Budaya. Jakarta: Rajawali Pers.

Silva, C.J., Magro, C.B.D., \& da Silva M.Z. (2016). Gender Inequality In Accounting Profession Form The Perspective Of The Glass Ceiling. Race, Joacaba, vol. 15, no. 2, p.447-474.

Stedham, Y., Yamamura, J., \& Satoh, M. (2003). Gender And Salary A Study Of Accountans In Japan. Abstract in Proceedings of The Academy of Business and Administrative Studies International Cofference, Vancouver, BC, Canada.

Sugiyono. (2015). Metode Penelitian Pendidikan (Pendekatan Kuantitatif, Kualitatif, dan R \& $D)$. Bandung: Alfabeta.

Sugiyono. (2017). Metode Penelitian Kuantitatif, dan $R \&$ D. Bandung: Alfabeta.

Pauli, S.K. (2013). All Of My Bosses Have Been Man - On Gender Structures In Real Estate Industry. Property management, 31,420-434

Pauli, S.K. (2016). Representations Of Gender Of Gender In Annual Report In The Real Estate Industry In Sweden. Property management, 34,5-17.

Riduwan, Akhmad. (2010). Semiotika Laba Akuntansi : Studi Kritikal- Posmodernis Derridean. Jurnal Akuntansi dan Keuangan Indonesia. 1, 7.

Sudarma, I. K. (2014). Fotografi. Yogyakarta : Graha Ilmu.

Sugihartati, Rahma. (2014). Perkembangan Masyarakat Informasi dan Teori Sosial Kontemporer. Jakarta: Kencana Prenadamedia Group.

Suwardjono. (2005). Teori Akuntansi: Perekayasaan Pelaporan Keuangan. Jakarta: Salemba Empat.

Treas, Judtih \& Tsuio Tai. (2016). Gender Inequality In Housework Across 20 European Nations. Lessons From Gender Stratification Gender Theories. Sex Roles, 74,495-511.

United Nation. (2020). Retrieved from www.un.org

Vaara, E., \& Tienari, J. (2002). Justification, Legitimization And Naturalization Of Mergers And Acquisitions: A Critical Discourse Analysis Of Media Texts. Organization, 9,275304.

Wirawan, T.A. (2017). Faktor-Faktor Yang Mempengaruhi Minat Mahasiswa Akuntansi FEB UGM Dalam Memilih Karir Sebagai Akuntan Publik. Skripsi. Fakultas Ekonomi dan Bisnis. Universitas Gadjah Mada: Jogyakarta.

Wulan, F.N. \& Yuniarto, A.F. (2015). Pengaruh Gender, Tekanan Ketaatan, Pengetahuan, Keahlian Dan Pengalaman Terhadap Kualitas Audit. Journal Universitas Ahmad Dahlan. 